\title{
Justice as Lawfulness ${ }^{1}$ \\ Tristan J. Rogers, University of Arizona \\ tristanjrogers1@gmail.com
}

Keywords: justice, virtue ethics, law, institutions, Aristotle

How is a just person related to the laws of a just society? Consider the classic case of Socrates. In Plato's Crito (1997b: 51b), Socrates argues that the just person should obey the law, unless it is possible to persuade the city that the law is unjust and should be changed. For this reason, having failed to persuade the city at his trial, Socrates accepts the unjust order of his execution, rejecting the offer from his friend Crito (and others) to help him escape. But, in the Apology (Plato 1997a: 32c), Socrates relates the fact that he refused an unjust order from the Thirty Tyrants to arrest Leon of Salamis. So, notwithstanding his arguments in Crito, sometimes the just person should disobey the law without first attempting to persuade. While one can certainly agree with Socrates that it is worse to commit injustice than suffer it, what distinguishes escaping (unjust) execution from refusing an (unjust) order? In other words, when and for what reasons should a just person disobey the law?

The question points to the need to be more precise about the relation between justice as an individual virtue and justice as an institutional virtue. The latter has been exhaustively explored by political philosophers, whereas the former remains underexplored in the literature on virtue ethics (Hursthouse 1999: 5-6). One possibility is that institutional justice is logically prior to individual justice, such that what is institutionally just structures the duties of individual

\footnotetext{
${ }^{1}$ Thanks to the following people for reading earlier versions of this article, which is based on Chapter Four of my (2017) Doctoral Dissertation Virtue Politics: Julia Annas, Mario Ivan Juarez-Garcia, Mark LeBar, Fred Miller Jr., John Proios, Gregory Robson, Daniel C. Russell, David Schmidtz, and Bjorn Wastvedt.
} 
justice. Call this the 'structural view' (LeBar 2014: 270-271). According to the structural view, a person is just insofar as they fulfill the duties prescribed by just institutions. An alternative to the structural view is the claim that individual justice is logically prior to institutional justice, such that just institutions are composed of the relationships between just persons. Call this the 'compositional view' (ibid.). According to the compositional view, a person is just primarily as a matter of character, and institutions are just insofar as they maintain the relations between just persons.

This paper defends a version of the compositional view and argues that it requires a conception of individual justice I call 'justice as lawfulness'. The resulting view consists of three claims. First, given the compositional view, just institutions are composed of the relations between just persons. Second, according to justice as lawfulness, the just person has a disposition to act in accordance with the legal and social norms (collectively, the nomoi) of an existing political tradition. Third, departures from the nomoi require that the just person act with practical wisdom to reform the nomoi according to a standard of justice implicit in an existing political tradition. The just person is a law-abiding agent of reform, charting a middle course between a political tradition, where justice is rooted, and a standard of justice, which is approached incrementally through the tradition.

Section (1) distinguishes two conceptions of individual justice: lawfulness and fairness. Section (2) considers the structural and compositional views of institutional justice, and argues on behalf of the latter. Section (3) rejects Mark LeBar's version of what I call a fairness conception of individual justice because it does not adequately serve the public justification function of law. Section (4) presents and argues for justice as lawfulness as an alternative because it does serve this function. Section (5) explains the role of social change in justice as 
lawfulness, warding off the charge that the view is essentially conservative. A brief conclusion returns to the example of Socrates as a moral exemplar of the just person.

\section{Individual Justice}

Following Aristotle (2000: 1105b), we can provisionally define the individual virtue of justice as a settled disposition of character to perform just acts with a) knowledge, b) sound emotion, and from c) rational choice (prohairesis). Aristotle also thinks of virtue as hitting a mean between two extremes of vice in terms of excess and deficiency, that is, performing the right action, with the appropriate emotion, at the right place, and at the right time. As some commentators have noticed, the virtue of justice fits uncomfortably within Aristotle's doctrine of the mean (Annas 1993: 312). But as I discuss later in discussion of justice as lawfulness's account of social change, there is a sense in which justice is a mean, or at least, as Aristotle puts it, 'a sort of mean' because 'it is related to a mean' (Aristotle 2000: 1134a).

Aristotle cites two ways in which a person is said to be unjust, reflecting two different senses of the positive Greek adjective dikaion: i) the unlawful person, and ii) the unfair/greedy person (Aristotle 2000: 1129a). Aristotle's observation forms the basis of a contrast between two broad conceptions of individual justice: a lawfulness conception and a fairness conception. According to a fairness conception, the lawful person and the just person are not necessarily the same, since some laws may be unfair from the standpoint of justice, and therefore are not acceptable to the just person. For this reason, the just person acts in accordance with what justice requires as a matter of fairness. Since existing laws, whether just or not, also raise considerations of fairness in terms of their equal application, the just person need not sanction lawlessness. But the lawful and the just remain distinct kinds of reasons. 
In contrast, the lawfulness conception asserts an identity: the just person $i s$ the lawful person. The just person will not act in accordance with what justice requires in any sense (fairness or otherwise) unconnected from what is lawful, understood as following the law of an existing political community. This use of 'law' is broadly consonant with F.A. Hayek (1973: 7273), who distinguishes the unguided evolutionary process of law from the deliberately designed and planned process of legislation. By following the law in the Hayekian sense, the just person follows and upholds the law of an existing political tradition, which, following John Kekes (1998: 38), is 'a set of customary beliefs, practices, and actions that has endured from the past to the present and attracted the allegiance of people so that they wish to perpetuate it'. The just person, on the lawfulness conception, has a disposition to abide by these norms, whereas on the fairness conception, the just person has a disposition to act in accordance with reasons of fairness, which may or may not support such norms.

Aristotle (2000: 1134b-1136a) distinguishes the just person from two other modes of justice: the just act and what makes something just. What makes something just, for Aristotle, is determined by whatever secures the happiness or flourishing (eudaimonia) of a political community's members (Aristotle 1998: 1282b15-1284a). And thus, the just act is an action that contributes to the happiness of a political community's members. Further, an act of injustice performed through ignorance or excessive emotion can be separated from acts that are performed from an unjust character, which, following Aristotle's account of virtue, requires choice and a settled disposition or habit. In addition to i) the just person, ii) the just act, and iii) what makes something just, we should also add for our purposes, iv) the just institution, understood as an institution that is in accordance with what makes something just. 
How are the four modes of justice related? One possibility is to begin with the just person. While sympathetic to the possibility, David Wiggins (2004: 487-491) observes that the notion of the just person seems to depend logically on a prior analysis of the just act (i.e. what acts the just person characteristically performs), which in turn depends on what makes something just (i.e. what features make those acts just). Indeed, this is precisely the point on which fairness and lawfulness conceptions of individual justice diverge. Further, what makes something just seems to be tightly connected to the idea of a just institution, since many questions of justice invoke or assume the existence of institutions that can be either just or unjust. But what makes an institution just? Must we, answer this question independently of the just person? Or, is there something central about the just person?

\section{Institutional Justice}

The structural view claims that the just person is not central to institutional justice. Instead, we should begin by trying to understand the justice of institutions and then think of the just person as someone who is disposed to uphold and follow the requirements of institutional justice. The compositional view, meanwhile, claims the opposite: we should begin by trying to understand the just person and then think of just institutions in terms of the relations that hold between just persons. This section examines these competing views in more detail, and argues for the compositional view,

While not explicitly identified, the compositional view has roots in ancient Greek ethical theory, particularly the 'depoliticized' outlook of the Stoics, who despite their emphasis on justice as an individual virtue, according to Julia Annas (1993: 311, emphasis added), '[did] not regard the justice of institutions as a centrally important ethical matter'. Despite its ancient roots, 
the possibility of a compositional view of justice seems to have been missed by contemporary political philosophers. For instance, responding to a possible objection that his treatment of justice is a break from the philosophical tradition represented by Aristotle, John Rawls writes, ‘Aristotle's definition [of justice] clearly presupposes.... an account of what properly belongs to a person and of what is due to him' (Rawls 1999c [1971]: 10). Moreover, 'such entitlements are...very often derived from social institutions and the legitimate expectations to which they give rise' (ibid.). But following the compositional view, one may argue that what properly belongs to a person, while logically connected to social institutions, cannot be reduced to a theory of justice for what Rawls calls 'the basic structure of society' (Rawls 1999c: 6). Instead, just institutions maintain the relations between just persons, and these institutions, which the just person has a disposition to recognize as just, define what properly belongs to a person.

While the compositional view is seldom noticed, the structural view has dominated contemporary political philosophy, especially since Rawls's (1999c [1971]) A Theory of Justice. The structural view maintains that justice is primarily a property of institutions. 'Justice,' in Rawls's famous phrase, 'is the first virtue of social institutions' (ibid.: 3). Moreover, we can develop an idea of what the institutions of a just society would be like. Theorizing about justice then normatively guides the evaluation of existing institutions. And this normative guidance extends to the just person, who is understood to have a disposition to follow and promote the institutions recommended or supported by the most plausible (or reasonable) theory of justice. As Rawls puts it, the duty of justice for individuals 'requires us to support and to comply with just institutions that exist and apply to us. It also constrains us to further just arrangements not yet established' (Rawls 1999c [1971]: 99). 
The structural view rightly focuses on institutions as a site of justice. This is an important contribution. However, the structural view fails to respond to the sense in which justice, as an individual virtue, is part of a virtuous life as a whole, which is the central normative concept of ancient virtue ethics (Annas 1993: 27-46). In modern philosophical language, the structural view divorces the reasons that motivate the just person, as part of a virtuous life, from the reasons that support the institutions of a theory of justice. Famously, for example, Rawls requires that we leave behind ideas about the good (and so virtue) in order to enter the original position and consider justice impartially behind the veil of ignorance. This creates a bifurcation in practical reasoning because institutions are not justified in terms of the virtues characteristic of a good life that an actual person might pursue, but in terms of an ideal theory of just institutions for ideally just persons. But when we cease to reason behind the veil of ignorance, ideally just institutions may or may not answer to the concerns of actual persons and how they conceive of the good for themselves and their communities.

One reason for this bifurcation in practical reasoning is Rawls's claim that the concept of the right is prior to the concept of the good (Rawls 1999c [1971]: 28). This means, among other things, that individuals have broad latitude to pursue different conceptions of the good so long as they are consistent with and (ideally) supportive of what institutional justice requires as a matter of right (Rawls 1999d [1988]: 449-450). In this regard, Rawls follows Henry Sidgwick (1981 [1874]: Bk. 1, Ch. 9) who thought of the right as an imperative notion, what we are required to do even if it does not appeal to us, whereas the good is an attractive notion, that is, what is a desirable (but optional) way to live (cf. Gaus 2011: 7).

However, with some exceptions (Watson 1990: 449-470), these philosophers have not noticed that the virtue of justice has both notions. Justice is a constraint because it requires or 
prohibits certain actions. This is the aspect of the right, justice as an imperative notion. This imperative sense of virtue supports what Hursthouse (1999: 36-39) calls 'v-rules', which are rules that follow from acting in accordance with the virtues. But justice is not simply an imperative notion. Justice is also a directive because it directs the virtuous person to be just, and to establish just institutions where possible, both of which we ought to desire because they are demanded by virtue. This is the aspect of the good, justice as an attractive notion. The main defect of the structural view, then, is that it does not adequately account for the directive aspect of justice; it might tell us what institutions are required by a theory of justice, but it doesn't integrate that idea into an attractive theory of the just person.

Rawls's structural view was evidently motivated to avoid a utilitarian version of a compositional view, according to which just institutions are defined in terms of satisfying the principle of utility for individuals. For the utilitarian, just institutions are composed of individuals who are just insofar as they act on the principle of utility through the medium of institutions. For this reason, Rawls observed, utilitarianism extends to 'society as a whole the principle of rational choice for one man' (Rawls 1999c [1971]: 24). And Rawls rejected utilitarianism because it allowed individual interests to be sacrificed when they were in service of the aggregate good. Hence, '[u]tilitarianism does not take seriously the distinction between persons' (ibid.). Can the same objection be made to compositional views generally? Does the compositional view of justice allow the sacrifice of the individual for the group? There is good reason to think the objection does not apply to a compositional view that takes virtue instead of utility as central. As Hursthouse explains:

The thought that motivates regarding utilitarianism as a threat is the thought that wrong or wicked acts regarding particular individuals can be 'justified' when they maximise the 
good of happiness....But a eudaimonia-based account gives no such reductive account of wicked or wrong acts. If a just law, determining a right, cannot, as things stand, be implemented in a particular society, without necessitating that some members of the society act wickedly or wrongly, then it cannot, as things stand, be implemented (Hursthouse 1991: 242, emphasis added).

The italicized portion of this passage is what Mark LeBar (2013b: 273) calls 'Hursthouse's Constraint'. According to LeBar, we should interpret Hursthouse's claim as setting a limit on the authority of political institutions, such that the individual good cannot be sacrificed for the overall good precisely because the good is understood in terms of virtue. In other words, Hursthouse avoids Rawls's objection to utilitarianism because she recognizes the constraining aspect of the virtue of individual justice. Individual justice constrains what can count as institutional justice because just institutions are composed of the relations between just persons.

To sum up this section, the virtue of justice has what I have called a constraining aspect and a directive aspect. I rejected the structural view because it does not adequately account for the directive aspect of justice. A theory of the virtue of justice should integrate both aspects, as the compositional view does. There is still a lingering issue, however, for we could understand individual justice either in terms of fairness or lawfulness, and this will make a difference in how we understand the claim that institutional justice is composed of the relations between just persons. The compositional view remains incomplete until we settle on a conception of individual justice that determines what it means for institutional justice to be composed of the relations between just persons. Thus, we need to examine more closely the fairness and lawfulness conceptions of justice as an individual virtue. 


\section{A Fairness Conception of Individual Justice}

While fairness has a strong association with post-Rawls egalitarian work on distributive justice (e.g. Cohen 2008), it is also an important concept in the classical liberal tradition (see Tomasi 2012: 96-99, 162-96). In recent work, following this tradition, LeBar (2014, 2013a, 2013b, 2009, 2005) defends a version of what I have called a fairness conception of individual justice that incorporates the Kantian idea of respect for persons in a way suitable to approaching issues in political philosophy from a virtue ethics perspective. LeBar's view is significant because, unlike Rawls and many subsequent political philosophers, who combine a fairness conception of individual justice with the structural view, LeBar defends the compositional view, and he does so from a virtue ethical perspective (LeBar 2014: 273-4). It is worthwhile therefore to examine LeBar's view as the main competitor to what I call 'justice as lawfulness'.

One form LeBar's view takes is an argument for 'a certain liberal conception of political authority - what is sometimes called 'justificatory liberalism' - [as] something virtue ethical theories have reason to endorse' (LeBar 2013b: 265, emphasis original). Justificatory liberalism is a liberal conception of the authority of political institutions that 'requires the justification of that authority to each individual subject to it' (Ibid.: 279). Drawing on Rawls (1993), justificatory liberals (or sometimes 'public reason liberals') ground their account of political authority in a conception of persons as fundamentally free and equal insofar as they are reciprocally placed to determine their obligations and duties (Gaus 2011: 14-35). No person, according to this view, has any natural or pre-existing obligation to obey another.

LeBar (2013b: 278, 2014: 267-270) argues that an understanding of this 'justificatory relationship' between persons is missing from virtue ethics, particularly in the ancient sources. To better understand the justificatory relationship, LeBar draws on work by T.M. Scanlon (1998) 
to propose that we see ourselves as standing in a relation of 'mutual recognition' with each other, and he identifies this relation as involving a virtue. LeBar cites the following passage from Scanlon:

The contractualist ideal of acting in accord with principles that others (similarly motivated) could not reasonably reject is meant to characterize the relation with others the value and appeal of which underlies our reasons to do what morality requires. This relation, much less personal than friendship, might be called a relation of mutual recognition. Standing in this relation to others is appealing in itself - worth seeking for its own sake (Scanlon 1998: 162, emphasis added).

Elsewhere LeBar (2014: 268-270) is clear that this relationship between persons is a way of understanding the reasons we have to respect persons, and that respect for persons is plausibly the core of an adequate conception of individual justice.

There are three Kantian elements to LeBar's conception of the virtue of individual justice. Each contributes to the idea that justice is about fair dealings with others. The first is the familiar Kantian principle of always treating persons as ends in themselves and never merely as means. Here the idea is that we cannot simply use other people as means to our own ends, since they have ends of their own sufficient to demand respect (LeBar 2013a: 10-14). A just person recognizes persons as ends in themselves. The force of the first Kantian idea leads to a second idea that the just person, in his relations with others, 'refrains from imposing his will on them in any way that is incapable of reciprocation' (LeBar 2014: 268-9). Thirdly, this recognition of reciprocal respect suggests that others have a kind of moral standing to demand that we treat them in ways that can be reciprocally justified. 
LeBar's version of what I call a fairness conception of individual justice places the idea of reciprocity at the heart of just relations between persons (See also Schmidtz and Thrasher 2014: 59-74). It is worth noting, however, that unlike most fairness conceptions in the vast literature on distributive justice, LeBar's focus on reciprocity only amounts to a formal conception of individual justice because it does not yield substantive conclusions about what actions are just (or unjust) in determinate circumstances. In this respect, LeBar's view is much closer to Rawls's earlier work (e.g., Rawls [1958] 1999a: 59-60), which linked justice and fairness through the idea of reciprocity (see Rawls [1971] 1999b: 190). Nevertheless, the just person, unlike on a lawfulness conception, acts on reasons of justice (as reciprocity or fairness), which are logically prior to what existing law requires. For LeBar, the just person is disposed to treat others as free and equal persons, deserving of respect and reciprocal justification for the imposition of duties and obligations. This is what it means to treat someone fairly according to reasons of justice. And since LeBar also defends the compositional view, institutional justice is constrained by the relations between just persons who act according to a principle of reciprocity in their fair dealings with each other.

LeBar's conception of individual justice rightly focuses on what we might term our 'accountability relations' with others, that is, the ways in which we feel ourselves required to justify our actions to each other as equal members of a political community. And plausibly, part of treating others fairly in this way is to respect their status as moral persons with ends of their own. But LeBar's attempt to determinate the scope and justification of our accountability relations is not successful. As I will argue, the issue of justifying our duties and obligations to one another is fundamentally about having a means of public justification, and this is a function that existing law uniquely serves. 
LeBar accounts for our evident substantive disagreements about justice by focusing on the higher order procedural question of how we justify our actions to each other (i.e. 'who gets to decide?'). And his answer is that we are reciprocally placed insofar as moral obligations must be justified to each person (e.g. each decides for themselves). But this formal principle of reciprocity cannot substantively determine what justice requires of/in our accountability relations with others. This is because such relations are essentially a matter of jurisdiction, and jurisdiction cannot be determined without first accounting for existing relationships, institutions and practices, many of which are publicly justified in terms of the laws of an existing political community, and few of which require reciprocal justification for the imposition of obligations and duties (e.g. the duties of family). To be sure, reciprocity might be a worthy ideal of how to act within our existing accountability relationships (friendship comes to mind), but it cannot determine or justify them a priori. As J.R. Lucas (1980: 27) puts it, '[the law] tells us not what is to be done in a situation, but who is to decide what shall be done. And to have the say is to have a right'.

The foregoing indicates that what LeBar refers to as the 'justificatory relation' between persons is something already embedded in the relationships, institutions, and practices that constitute a political community and make up the pre-theoretical given of ethical life. Such entities determine our relationships to others in ways that make our obligations and duties transparent, even if not fully determinant. In this way, we have what Michael Hardimon (1994: 333-363) calls 'role obligations', e.g. the obligations of family members, citizens, members of organizations, and so on. But what these obligations amount to concretely must be worked out in practice by individual persons in their peculiar circumstances. They cannot be determined by a theory of justice. This is partly because the virtues do not provide moral guidance that is 
reducible to a set of principles, much less a single virtue like justice (McCloskey 2006: 346-368).

Rather, the virtues (including justice) consist in the proper way of acting - virtuously - within our existing relations with others (Annas 2002: 103-123). The just person recognizes the normative status of these relations and acts well within them, thus serving as an ideal of the virtuous person toward which we aim.

\section{$\underline{\text { 4. Justice as Lawfulness }}$}

Justice as lawfulness begins from the premise just stated, namely, that the virtuous person always acts in the context of a shared social structure. According to justice as lawfulness, the just person is disposed to act in accordance with the nomoi of her political community. I use the ancient Greek term nomoi deliberately to indicate the usefully broad sense of 'law' in ancient Greek political thought. As Richard Kraut explains,

[W]hen [Aristotle] says that a just person, speaking in the broadest sense is nomimos, he is attributing to such a person a certain relationship to the laws, norms, and customs generally accepted by some existing community. Justice has to do not merely with the written enactments of a community's lawmakers, but with the wider set of norms that govern the members of that community. Similarly, the unjust person's character is expressed not only in his violations of the written code of laws, but more broadly in his transgression of the rules accepted by the society in which he lives (Kraut 2002: 105-6). While the ancients did not make Hayek's distinction between the processes of law and legislation, Aristotle (1998: 1287a-187b10) does recognize the general superiority of customary law over written law. Since legislation may be a necessary part of a legal tradition based in law, I use 'nomoi' to encompass both as well as the broader sense indicated by Kraut. 
Given this understanding of nomoi, in terms of Aristotle's four modes of justice (see section I), justice as lawfulness consists of the following four claims. First, what makes something just refers to the nomoi. Second, a just act is an action performed in accordance (or not in conflict) with the nomoi. Third, the just person acts from a settled disposition to observe the nomoi, not out of blind obedience, but as a virtue, chosen with knowledge and sound emotion. Finally, given the compositional view, a just institution will be an institution that maintains the relations between just persons, viz. an institution that is in accordance with the nomoi.

The critical role of the nomoi in understanding the virtue of justice is that they function as public judgments for how persons should relate to each other. They constitute what LeBar calls the 'justificatory relation'. The nomoi structure our relationships with and consequent obligations to others. A thoroughly lawless society (Durkheim's 'anomie') is one in which persons act solely based on their own judgment without regard to their relationships within the broader community. While there can never be complete unanimity, full transparency, or determinacy in the nomoi of a society, the public nature of law, either written or informal, allows people to interact beneficially, since they know what to expect from each other. Law is the institutionalization of trust.

Justice as lawfulness is superior to a fairness conception of justice because it captures the sense in which existing law serves the function of public justification. We determine our accountability relations with others by referring to the offices and relationships that are defined by the institutions and practices of an existing political tradition, expressed by/in its nomoi. This is not a Rawlsian constructivist conception of public justification understood as public reason, but rather a conception of public justification that accounts for the actual role played by 
institutions and practices in ordinary moral life. Justice as lawfulness focuses on public practices rather than public reason.

Constructivist accounts of public justification appear partly motivated by what Rawls calls 'the fact of reasonable pluralism' (Rawls 1999e [1997]: 765-6). For it is thought that we need a way to model and explain how the diversity of values that exist in modern societies can morally coexist with the coercive nature of political institutions (Larmore 1994: 61-79). While the fact of reasonable pluralism is important, especially with respect to competing conceptions of the virtues in a society, I believe it carries too much weight in the discussion of public justification. Any stable society characterized by reasonable pluralism also consists of a set of shared beliefs, the nomoi. Reasonable pluralism is only possible if there exists some set of stable beliefs about how groups with fundamentally different belief systems ought to behave toward one another. Otherwise, while pluralism may temporarily flourish, in the long run, chaos is inevitable. And it is a virtue of justice as lawfulness that it recognizes the important function of these stabilizing beliefs, as realized in the laws and institutions of existing political communities.

We are now able to reconsider Hursthouse's contribution that individual virtue - more specifically individual justice - is a constraint on institutional justice. How does the just person, who is disposed to follow the nomoi of her community, help us understand institutional justice? Since the just person upholds and follows the nomoi, which consist of both legal and social norms, we can start by thinking about the relationship between these two kinds of norms. The legal theorist Lawrence Solum (2008: 188-9) proposes three forms this relationship can take:

1. Congruence: a legal norm can be congruent with a social norm (or vice versa), e.g. criminal laws against murder. 
2. Support: a legal norm can be supported by a social norm, e.g. social norms about which authority determines the rules of the road (i.e. a public transport authority).

3. Inconsistency: a legal norm can be inconsistent with a social norm, either in terms of a) content or b) lack of recognized authority.

The congruence relation is one that raises no special problems from the standpoint of justice. When legal norms are congruent with social norms, there exists a harmony between what the (positive) law requires and what the community believes the law ought to require as a matter of justice. The same legal norm, of course, will be incongruent if it is exported to a place where the appropriate social norms do not exist (e.g. exporting democracy to parts of the Middle East). The support relation is similarly unproblematic. Every functioning society relies on social norms that sanction specific authorities to have jurisdiction over some realm of social life, such as a public transport authority. The just person is disposed to recognize these authorities, where established by the legitimately made law of a political community.

The crux of individual justice as a constraint on institutional justice resides in the inconsistency relation. Following Solum (2008: 188-9), inconsistencies between legal and social norms can take at least two forms: a) conflict in content, and b) conflict in recognized authority. I would also add c) conflict in implementation. What does the just person do when faced with such conflicts? Either she acts on the legal norms, in which case she is betraying the social norms, or she acts on the social norms, in which case she is betraying the legal norms. Neither preserves the just person as a lawful person.

First, consider a conflict in content. In cases of new or proposed legal norms, it is easy to see how social norms that are part of an established political tradition take precedence. For instance, if a civil authority attempted to pass a law of mandatory government informing on 
fellow citizens, this would violate a clear social norm regarding privacy in the United States. We also have norms about which institutions have recognized authority to perform certain functions. For example, there are norms sanctioning the traffic management authorities to regulate speed on public highways, but a traffic authority that mandated what color cars may drive on the highways would be grossly overstepping its mandated authority. The point, in both cases, is not that the prior social norm has been around for a long time, but rather that it has persisted as part of a political tradition that has successfully met the needs of its citizens, who look to their political tradition as a constitutive good in their lives, a good that allows them to cooperate peacefully for their mutual benefit. The just person, then, has a disposition to uphold and defend such a tradition from the encroachment of political, social, and individual forces.

A third possibility is a law that, while having some plausible justification, requires action that is inconsistent with a social norm in its implementation. This seems to be the kind of case Hursthouse had in mind with laws that require persons to engage in vicious activity. If, for instance, there is some justification for a law prohibiting certain drugs, but in practice the enforcement of the law requires the authorities to treat minor drug offenders in an inhumane way (as arguably the 'War on Drugs' does), there is some reason to think that the law as such is inconsistent with a social norm, and therefore not a law acceptable to the just person, at least in the vicious form of implementation.

I close this section with what the reader may have felt as a lingering objection that sets up the final section's discussion of social change. I have explained the constraint of individual justice in terms of the relationship between legal and social norms (collectively, the nomoi), where the just person has recourse to one or the other to maintain the constraint of justice. But what should be said if the nomoi themselves are vicious or unjust? How does justice as 
lawfulness account for unjust nomoi? For the view seems to depend on the Aristotelian claim that the nomoi reliably track the happiness (eudaimonia) of the members of a political community. But we know this is often not the case, as illustrated by the antebellum South where both the legal and social norms marginalized and brutalized the slave population, or in other cases, where institutions fall short in less extraordinary, but altogether unsurprising ways. As I will argue, this is why justice as lawfulness needs to be understood in conjunction with practical wisdom (phronesis), so that the nomoi can be reformed in accordance with an implicit standard of justice that the just person approaches incrementally through the political tradition in which he acts.

\section{Unjust Laws and Social Change}

Part of the task of this final section is to explain why justice as lawfulness is not essentially conservative. For the requirement that political institutions are constrained by the existing nomoi of a political community might seem unduly prejudiced toward the status quo and hostile to new proposals for beneficial social change. Indeed, one of the attractions of the structural view when combined with a fairness conception, which dominates contemporary political philosophy, is that it begins from the premise that existing institutions are very likely unjust (because unfair) and therefore must be made just in accordance with a theory of (institutional) justice. Undoubtedly fairness - especially political equality - has been an important value in the development and spread of liberal societies. But fairness is a multidimensional and highly contested political value, and it is unclear how to construct an ideal of justice that can serve the function of public justification in a political society characterized by substantive disagreement. 
An important feature of the nomoi is that they are bounded in time and place. They are the path-dependent result of successful responses to social problems that existed in the past, to which their mere existence testifies. The existing norms of a political community are successful because they have gone through a process of social evolution; they have answered to an implicit standard of justice that is grounded in solving the perennial problems of social life. The nomoi of a society are justified not because they comport with an ideal theory of justice, but because they approximate ideal solutions to non-ideal problems (Schmidtz 2016: 9). And since one of our non-ideal problems is the imperfectability of human beings, we must continually fine-tune our institutional instruments to adapt to our own fallibility (Russell 2012: 268).

What's more, changes in the moral and social landscape, e.g. new economic conditions, will necessitate reform, since old solutions may be maladapted to new problems. For example, while contingencies having to do with the division of labor made women's participation in politics a near impossibility in earlier ages of human society, economic progress and social change toward the end of the $19^{\text {th }}$ century made the prospect seem desirable to enough people to democratically win women's suffrage. In this case, women (and men) sought to reform the existing social norms of their time that confined women to a fixed gender role in society. Why, as John Stuart Mill argued, should women not be given a fair chance to succeed on the same terms as men? It is tempting to view Mill's plea as an appeal to a theory of institutional justice or a theory of fairness. But arguably Mill wasn't trying to replace an old social norm with a new one. He was trying to reform the existing social norm, that political participation is reserved for those who are capable of political deliberation and action, to include the other half of the population, who, in Mill's estimation, eminently met that criteria. 
The necessity of new proposals for social change is grounded in the fact that over time the nomoi of a society inevitably ossify. Part of the reason for that ossification is natural decay. But it is also the result of human iniquity, fallibility and our inability to keep pace with the dynamics of a complex society. It is, therefore, the responsibility of the just person not only to abide by the existing nomoi, but to reform the nomoi when necessary and possible, so that the political tradition can be revived and perpetuated. In the immortal words of Edmund Burke (1999 [1790]: 108), '[a] state without the means of some change is without the means of its conservation'. Correspondingly, a state without just persons is without the means of its change.

According to justice as lawfulness, change - at least salutary change - comes about because of the just person, who looks to change the nomoi, not by reference to abstract considerations of justice, but by reforming the existing nomoi in a way that improves upon the existing political tradition, thus sustaining it across time. This change in individual judgment, represented by the just person, then eventually becomes widespread enough to change the nomoi, and ultimately, though perhaps slowly and uncertainly, move the political community closer to an ideal of justice. For instance, refusing people opportunities and services based on an immutable characteristic (i.e. race) was once an accepted and widely practiced social norm in the United States. But over time individual judgments about the evils of this practice consolidated to make this kind of discrimination one of the worst transgressions of a social norm one can commit.

The individual moral judgment of the just person alerts us to ways in which the nomoi are deficient, and therefore fall short of a standard of perfect justice that is imperfectly embedded in the institutions of a political tradition. But attempts to transform existing institutions to satisfy an ideal of justice can be quixotic or even dangerous if they are not based on shared judgments, 
which must balance contested ideals of justice with the very real risks of social change. This is one reason why just persons must argue for their reform proposals in public, and if they are to be persuasive, ground their proposals in the ideals of a shared political tradition. Like Martin Luther King's pronouncements on the evils of segregation - pronouncements which were deeply grounded in the highest ideals of the American political tradition - such proposals have the power to reform the nomoi over time, if only they are heard and considered. Likewise, harmful proposals can be heard and defeated.

The nomoi must also include second order judgments about justice, i.e. what kinds of social arrangements are considered just by the community. These judgments are widely shared by definition. Such judgments can create social pressure to reform legal norms that are no longer considered just, which is to say they no longer serve the function of maintaining a society that is perceived as just by its members. The process can also work in the other direction. For sometimes the social norms are defective and new legal norms must be won politically to exert downward pressure on obstinate persons to change their behavior.

This process of balancing justice with the vagaries of political and social change requires care and above all, practical wisdom. The distinguishing feature of justice as lawfulness is that it places the emphasis on reform from an initial place of conformity, rather than transformational or revolutionary change. On the one hand, insisting that institutions conform to an ideal of justice without paying attention to the existing nomoi undermines the very institutions that make reform possible. On the other hand, maintaining manifestly unjust institutions for the sake of short-term stability can undermine the long-run legitimacy of existing institutions and fail to respond to the dynamic needs of a complex society. While there is no perfect balance between stability and change, and there are no guarantees that the just person will be successful in achieving a 
recognizably just (much less liberal) society, justice as lawfulness nevertheless locates justice in the actions of just persons, rather than the design of just institutions.

I have drawn the basic contrast between the structural and compositional views as residing in the relative logical priority given to either just institutions or just persons in the order of explanation. But as Annas (1993: 316) observes, Aristotle, whom I have taken as a paradigm of the compositional view, 'has much to say about both [i.e. just institutions and individuals], and, in his usual fashion, has no drive to reduce one to the other or to force them under a specific common account'. While I have defended the compositional view over the structural view, I believe the view Annas attributes to Aristotle is right, and justice as lawfulness explains why. The just person is disposed to follow the nomoi. But the nomoi are inextricably linked to the institutions of an existing political community. And so, if existing institutions are in accordance with the nomoi of a political community, the just person qua lawful person is, in effect, someone who follows just institutions (per the structural view). However, institutions are just not because they comport with a theory of just institutions, but because they are in harmony with the nomoi of a political community (contra the structural view). So, while justice may or may not be 'the first virtue of social institutions', the just person strikes a necessary balance between justice (as lawfulness) and the other virtues of a good society (e.g. efficiency, fairness, artistic achievement, etc.).

This last idea is why I believe justice as an individual virtue can be usefully understood in terms of a mean. Aristotle famously defines virtue as a mean with respect to a vice of excess and a vice of deficiency. These are two ways of going wrong. For example, the temperate person avoids gluttony (excess) and asceticism (deficiency) with respect to bodily pleasures. The virtue of justice, it has been argued by Bernard Williams (1980: 189-200) and others, allegedly does 
not fit this model because there seems to be no special feeling associated with justice, no corresponding way to do the just thing in a way intermediate between two unjust things, being either too just or not just enough. According to justice as lawfulness, however, there remains a sense in which justice is a mean between two ways of going wrong. The two ways of going wrong are: a) excessive conformity to existing law/institutions without regard for reform, and b) deficient regard for existing law/institutions in pursuit of an ideal of justice. Hence, justice is a mean, either between an excess of stability and a deficiency of change, or an excess of change and a deficiency of stability. Justice is a matter of getting it right.

\section{Conclusion}

In closing, it is worth noting that justice as a mean corresponds to the constraining and directive aspects of justice identified in Section (2). Justice as lawfulness requires that persons abide by the legal and social norms of their communities. In this sense, justice is a constraint on both individual action and institutional design. But justice as lawfulness also requires that the just person have a critical perspective on the social structure in order to reform it when necessary and possible. In this sense, justice directs us to revivify the social structure that enables us to live virtuously. Thus, on my view, the questions 'how should I act?' and 'what should our institutions be?' are tightly connected. We should act to preserve our existing institutions while working to reform them when necessary and possible through virtuous activity.

I began by asking why Socrates refuses the unjust order he describes in the Apology, while he accepts the unjust outcome of a very different order in Crito. The full answer should now be evident. Socrates accepts his punishment and refuses to flee in Crito because he accepts, as a matter of individual justice, the nomoi of his political tradition. To flee punishment, even 
unjustly deserved, would be an act of injustice, and therefore is unacceptable to a just Socrates.

Meanwhile, Socrates refuses the unjust order to arrest Leon of Salamis in the Apology because he is constrained by justice, which directs him not to recognize the authority of the Thirty Tyrants, since that institution acted outside the constraints of the Athenian political tradition to which Socrates belonged. In this respect, Socrates anticipates the natural law theorists in holding that lex iniusta non est lex (an unjust law is no law at all).

\section{$\underline{\text { References }}$}

Annas, Julia. (1993) The Morality of Happiness. New York: Oxford University Press.

Annas, Julia. (2002) 'My station and its duties: Ideals and the social embeddedness of virtue'. Proceedings of the Aristotelian Society, 102, 109-123.

Aristotle. (1998) Politics. C.D. Reeve (ed.). Indianapolis, IN: Hackett Publishing.

Aristotle. (2000) Nicomachean Ethics. Roger Crisp (ed.). Cambridge: Cambridge University Press.

Burke, Edmund (1999 [1790]) Reflections on the Revolution in France. Indianapolis, IN: Liberty Fund.

Cohen, G.A. (1997) 'Where the action is: On the site of distributive justice'. Philosophy \& Public Affairs, 26, 1, 3-30.

Gaus, Gerald. (2011) The Order of Public Reason. Cambridge: Cambridge University Press. Hardimon, Michael O. (1994) 'Role obligations'. The Journal of Philosophy, 91, 333-363. Hayek, F.A. (1973) Law, Legislation and Liberty, Vol. 1. Chicago: University of Chicago Press. Hursthouse, Rosalind. (1991) 'After Hume's justice'. Proceedings of the Aristotelian Society, 91, 229-245.

Hursthouse, Rosalind. (1999) On Virtue Ethics. New York: Oxford University Press.

Kekes, John. (1998) A Case for Conservatism. New York: Cornell University Press.

Kraut, Richard. (2002) Aristotle. Oxford: Oxford University Press.

Larmore, Charles. (1994) 'Pluralism and reasonable disagreement'. Social Philosophy and Policy, 11, 1, pp. 61-79.

LeBar, Mark. (2005) 'Eudaimonist autonomy'. American Philosophical Quarterly, 42, 171-184.

LeBar, Mark. (2009) 'Virtue ethics and deontic constraints'. Ethics, 119, 642-671.

LeBar, Mark. (2013a) The Value of Living Well. Oxford: Oxford University Press.

LeBar, Mark. (2013b) 'Virtue and politics'. In Daniel C. Russell (ed.), The Cambridge Companion to Virtue Ethics (Cambridge: Cambridge University Press), pp. 265-289.

LeBar, Mark. (2014) 'The Virtue of justice revisited'. In Van Hooft and Athanassoulis (eds.), The Handbook of Virtue Ethics (London: Acumen Publishing), pp. 265-275.

Lucas, J.R. (1980) On Justice. Oxford: Clarendon Press.

McCloskey, Deidre. The Bourgeois Virtues: Ethics for an Age of Commerce. Chicago, IL: University of Chicago Press. 
Plato. (1997a) Apology. In John Cooper (ed.), The Complete Works of Plato (Indianapolis: Hackett Publishing), pp. 17-36.

Plato. (1997b) Crito. In John Cooper (ed.), The Complete Works of Plato (Indianapolis: Hackett Publishing), pp. 37-48.

Rawls, John. (1999a [1958]) 'Justice as fairness'. In Samuel Freeman (ed.), Collected Papers (Cambridge: MA: Harvard University Press), pp. 47-72.

Rawls, John. (1999b [1971]) 'Justice as reciprocity'. In Samuel Freeman (ed.), Collected Papers (Cambridge: MA: Harvard University Press), pp. 190-224.

Rawls, John. (1999c [1971]) A Theory of Justice, Revised Edition. Cambridge, MA: Harvard University Press.

Rawls, John. (1999d [1988]) 'The Priority of right and ideas of the good'. In Samuel Freeman (ed.), Collected Papers (Cambridge: MA: Harvard University Press), pp. 449-472.

Rawls, John. (1993) Political Liberalism. New York: Columbia University Press.

Rawls, John. (1999e [1997]) 'The Idea of public reason revisited'. In Samuel Freeman (ed.), Collected Papers (Cambridge: MA: Harvard University Press), pp. 573-615.

Russell, Daniel C. (2012) 'What virtue ethics can learn from utilitarianism'. In Eggleston and Miller (eds.), The Cambridge Companion to Utilitarianism (Cambridge: Cambridge University Press), pp. 258-279.

Scanlon, T.M. (1998) What We Owe to Each Other. Cambridge, MA: Harvard University Press.

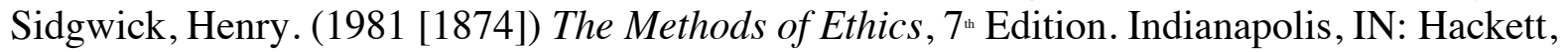
Publishing.

Schmidtz, David and Thrasher, John. (2014) 'The Virtues of justice'. In Kevin Timpe and Craig Boyd (eds.), Virtues and Their Vices (Oxford: Oxford University Press), pp. 59-74.

Schmidtz, David. (2016) 'A Realistic political ideal'. Social Philosophy and Policy, 33, 1-2, pp. 1-10.

Solum, Lawrence. (2008) 'Natural justice: an aretaic account of the virtue of lawfulness'. In Farrelly and Solum (eds.), Virtue Jurisprudence (New York: Palgrave MacMillan), pp. 167-192.

Tomasi, John. (2012) Free Market Fairness. Princeton, NJ: Princeton University Press.

Watson, Gary. 'On the primacy of character'. In Flanagan and Rorty (eds.), Identity, Character, and Morality (Cambridge, MA: MIT Press), pp. 449-470.

Wiggins, David. (2004) 'Neo-Aristotelian reflections on justice'. Mind, 113, 477-512.

Williams, Bernard. (1980) 'Justice as a virtue'. In Amelie Rorty (ed.), Essays on Aristotle's Ethics (Berkeley: University of California Press), pp. 189-200. 